Turkish Psychological Counseling and Guidance Journal

Türk Psikolojik Danışma ve Rehberlik Dergisi
Şimșek Öcal \& Ceyhan (2021)

Vol: 11 Number: 62 Page: 333-350 ISSN: 1302-1370

\title{
The Disease Process Experiences of Women Diagnosed with Breast Cancer in the Psycho-Social Context
}

\author{
Meme Kanseri Tamılı Kadınlarm Psiko-Sosyal Açıdan Hastalık Sürecindeki Yaşantılarmmn İncelenmesi
}

\section{Didem Şimşek Öcal ๑, Aydoğan Aykut Ceyhan ๑}

Authors Information

Psychological Counselor, MEB, Eskişehir, Turkey

smskpdr@gmail.com

\section{Aydoğan Aykut Ceyhan}

Professor, Anadolu University, Eskişehir, Turkey aceyhan@anadolu.edu.tr

\begin{abstract}
This study aims to reveal how women diagnosed with breast cancer experience the disease process in the psychosocial context. The participants of the phenomenological designed study consisted of 10 women diagnosed with breast cancer. The findings that were obtained through semi-structured interviews centered around the themes of responses to the disease, coping strategies, sources of social support, and existential reflections. With regards to the responses to the disease, the participants' responses when diagnosed with breast cancer were under the sub-themes of shock, emptiness, mental breakdown, inability to accept the diagnosis, despair, seeking social support, anxiety, and self-blame; and after the diagnosis, they were under the sub-themes of acceptance, anxiety, sadness, and helplessness. The coping strategies used by the women included the sub-themes of coping through spirituality, social support, obtaining information, exercise, and nutrition. The social support sources of women fell under the sub-themes of spouse support, friend support, support of other family members, and physician support. In terms of existential reflections, the women were found to have experienced the sub-themes of maturing, reinterpreting life, and facing death.
\end{abstract}

\begin{tabular}{|c|c|}
\hline Article Information & ZET \\
\hline Keywords & e kanseri tanısı alan kadınların hastalık sürecini psiko-sosyal \\
\hline Cancer & bağlamda nasıl deneyimlediklerini ortaya koymaktır. Fenomenolojik desende yapilan \\
\hline & arastırmanin kattlimcilarinı 10 meme kanseri tanilı kadin olusturmustur. Yar1 \\
\hline Copin & $\begin{array}{l}\text { vapilandırılmıs görüsmelerle elde edilen bulgular, psikososval bağlamda hastalık } \\
\text { valla }\end{array}$ \\
\hline $\begin{array}{l}\text { Socia } \\
\text { Exist }\end{array}$ & ilen tepkiler, başa çıkma stratejileri, sosyal destek \\
\hline Anaht & insımalar temalarında toplanmıştır. Hastalığa verilen tepkiler \\
\hline & ların meme kanseri tanısı aldığında şok, boşluk, ruhsal çöküntü, \\
\hline & ma kavol ve kendini suclam \\
\hline atejileri & sonra ise kabullenme, kayg1, üzüntü ve acizlik alt temalarında tepki verdiklerini \\
\hline & göstermiştir. Kadınların kullandıkları başa çıkma stratejileri ise maneviyat, sosyal destek, \\
\hline & zersiz ve beslenme yolu ile başa çıkma alt temalarını içermiştir. Sosyal \\
\hline & \\
\hline & \\
\hline & $\begin{array}{l}\text { hastalık sürecinde olgunlaşma, yaşamı yeniden anlamlandırma ve ölümle yüzleşmek alt } \\
\text { temalarına sahip olduğu bulunmuştur. }\end{array}$ \\
\hline \multicolumn{2}{|c|}{$\begin{array}{l}\text { Cite this article as: Şimşek Öcal, D., \& Ceyhan, A.A. (2021). The disease process experiences of women diagnosed with breast } \\
\text { cancer in the psycho-social context. Turkish Psychological Counseling and Guidance Journal, 11(62), 333-351. } \\
\text { https://doi.org/10.17066/tpdrd.1001704. }\end{array}$} \\
\hline
\end{tabular}




\section{INTRODUCTION}

Today, one of the most important life events that seriously affects human life and threatens its existence is pandemic, but another is to be diagnosed with cancer. The data of the World Health Organization (2018) indicate that cancer is one of the most common diseases today, with 18.1 million new cases. Cancer is a disease directly related to stressful life events (Ahadi et al., 2014). It not only has serious psychosocial effects on human life but also threatens the lives of its patients with uncertainty and obscurity (Elbi, 2001). There are many different types of cancer, one of which is breast cancer that often occurs in women.

Breast cancer is a disease that should be carefully considered in terms of the fact that it turns all aspects of women's lives upside-down, and in connection with its effects and reflections on the disease process, because being diagnosed with breast cancer can be perceived as a very challenging experience for women. Due to the diagnosis of breast cancer, women experience intense stress; their lives are negatively affected; and they may perceive this disease as destruction (Taleghani et al., 2006). The literature findings also show that, from the moment they learn about their disease, women cannot accept the disease (Çömez \& Karayurt, 2016; Hajian et al., 2017; Dsouza, et al., 2018; Lie et al., 2018); they feel hopeless (Inan et al., 2016) and sorry for being diagnosed (Tunç, 2014; İnan et al., 2016; Hammoudehet al., 2017; Lam et al., 2018), like they are near death (ALmegewly et al., 2019; Ghaemi et al., 2019); they perceive their body negatively (Landmark \& Wahl, 2002); their quality of life decreases (Yeter et al., 2009); they can experience emotional distress, problems in family and social relationships (Babacan Gümüş, 2006), anxiety, and depression (İnan et al., 2016; Hammoudeh et al., 2017; Dsouza et al., 2018); and, they can perceive the disease as a threat to female identity (Özkan \& Alçalar, 2009). Thus, all the adaptation skills of women who have to struggle with all these negative physical and psychological effects brought on by the disease are shaken, which leads them to review their whole life and make new arrangements to readapt to this stressful situation (Moadel et al., 1999).

In the literature, it is stated that in addition to the diagnosis, possible treatment methods such as chemotherapy, radiotherapy, mastectomy, etc. might increase the stress levels of women and negatively affect their ability to cope with stress effectively (Curtis et al., 2014) since they do not know exactly what to expect. In this context, besides psychological support, it is thought that meeting the social support needs of women with breast cancer, including the support from their spouse, children, other family members, and circle of friends, may have an important contribution to the physical and psychological well-being of these women (Finfgeld-Connett, 2005). Therefore, women diagnosed with breast cancer need professional psychological support. For this reason, it is quite valuable to enable women with breast cancer to obtain qualified psychological and social support whenever they need it, to increase their level of adaptation to the disease in line with this support, and to have effective coping strategies for challenging conditions. Furthermore, related studies reveal that women diagnosed with breast cancer seek social support when they learn about their disease (Tunç, 2014; Almegewly et al., 2019; Drageset et al., 2020). In this context, primarily the social support of their immediate surroundings becomes crucial for women with breast cancer. The people around women with breast cancer experience the disease as much as the women, and they can also be heavily affected by this situation. On the other hand, women with breast cancer should seek the psychosocial support they need during this challenging experience from the people close to themselves. 
It should be kept in mind that breast cancer is increasing among women today. Thus, more studies should be conducted to understand and explain the disease process experiences of women diagnosed with breast cancer. In addition, in terms of cancer types, being diagnosed with breast cancer is a very traumatic experience for women as women's self-esteem and self-confidence are impaired due to concerns such as loss of an organ, loss of attractiveness, and loss of their spouse. At the same time, they feel that their integrity of life is under threat (Özkan, 1993). Thus, the need to examine the experiences during the breast cancer disease process is crucial. Within this scope, it is predicted that revealing what women diagnosed with breast cancer experience in the disease process will make significant contributions to mental health professionals who will work with individuals going through this tough life event. In this context, this study aims to present in-depth how women with breast cancer experience the disease process in the psychosocial context.

\section{METHOD}

This study was carried out based on the phenomenological design of the qualitative research method.

\section{Participants}

The participant group consisted of 10 women who were diagnosed with breast cancer and underwent surgical intervention or received chemotherapy, radiotherapy, and medication due to the diagnosis. The participant group was determined by criterion sampling method, one of the purposive sampling methods. Thus, it is based on studying all cases that meet the criteria determined by the researcher or were previously established (Yıldırım \& Şimşek, 2016). In this context, the participation criteria for women diagnosed with breast cancer were determined as being over the age of 18, being diagnosed with Stage I breast cancer, continuing outpatient treatments (chemotherapy, radiotherapy, or hormone therapy), or having completed their systemic treatments, having 6-month or annual check-ups, being able to read and write, having no health issues regarding communication, and volunteering to participate in the study.

All participants reside in the city center. 8 of the participants are married while the other 2 are single. Participants who are married have at least one or two children. All participants are in the middle age group (age range 35-55). 6 of the participants were still working. The education level of the participants is as follows: one is a primary school graduate, one is a secondary school graduate, and the other 8 are at least a university graduate at the bachelor's level. 6 of the participants underwent a mastectomy, while 4 had cystectomy surgery. 3 of the participants received psychological help after breast cancer treatment (one of whom had one session).

To collect data, an interview form was used. The interview form was prepared in the study by the researchers for women diagnosed with breast cancer. The interview form consisted of two parts. The first part included demographic information such as age, education level, and marital status, and short questions about breast cancer. The second part had 11 open-ended questions aimed to obtain in-depth data regarding how women were diagnosed with cancer, what they experienced after the diagnosis, how they reacted, the difficulties they faced and how they coped, what life meant for them after the diagnosis, what did and did not support them in this process. In developing the forms, first, the draft forms were submitted to two experts for their approval. The draft forms were piloted with two participants diagnosed with breast cancer (28 minutes \& 30 minutes). In line with these interviews' data, the comprehensibility of the questions was revised and the forms were finalized after getting opinions from the two experts. 


\section{Ethical Statement}

The authors declare that they continue to work in accordance with scientific study ethics and the Helenski declaration in this study. All participants whose informed consents were obtained took part in this study as volunteers. In line with this, the study was investigated and permitted by Anadolu University Scientific Research and Ethical Review Board (REF: 5900-13.01.2017). Required permits were obtained to use the interview form in this study. The participants were informed of the goals of the study and they were told that their identities would be kept confidential

\section{Procedure and Data Analysis}

First, the ethics committee and application approvals were obtained in the study. In determining the participants, the criterion sampling method was used. Thus, the study was conducted with the participants who voluntarily accepted to participate in the study and met the specified criteria. The researcher initially aimed to determine the participants by collaborating with health facilities and hence to carry out the study with women currently being treated at research hospitals; however, she could not do so because required permissions were not granted. For this reason, the researcher reached potential participants via friends in her social circle who informed the people they know about this study. A preliminary interview was held by the researcher with the people who accepted to participate in the research voluntarily and met the predetermined criteria. In this preliminary interview, detailed information about the research was given; their consent was obtained; and, the interview was scheduled. Afterward, interviews were held with the participants on the scheduled day and time. The semi-structured interviews were conducted face to face by the first researcher. Permission for sound recording was taken from the participants. Notes were taken during the meeting with a participant whose permission could not be obtained. The duration of the interviews ranged from 27 to 69 minutes (average 69 minutes). In addition, in the present study, it was planned to conduct second interviews with the participants given that, in a research based on the phenomenological design, the experience (phenomenon) experienced by the participant is questioned in detail and the psychological essence of the phenomenon is tried to be obtained (Akturan \& Esen, 2013). In this context, the second interview aimed both to confirm whether the researcher understood the participants correctly or not, and to reconsider and deepen the points that were not sufficiently understood in the first interview. For this reason, among the participants, six women with breast cancer who agreed to the re-interview were interviewed for the second time. The second interview lasted between 11-45 minutes (average 24 minutes). In the study, due to the difficulties encountered in reaching the participants, the data collection process could be carried out for a year between May 2018 and May 2019.

In the study, the data obtained with the face-to-face interview method were analyzed with the inductive content analysis approach. In the content analysis, stages used in analyzing qualitative research data, such as coding data, finding themes, organizing codes and themes, defining and interpreting findings (Yildirım \& Şimşek, 2016) were followed. During the analysis, the coding was carried out by the researchers, and the NVivo11 qualitative data analysis software was used in the analysis of the data.

To ensure the credibility of the study, the data was diversified by referring to the interview and the research log during the data collection. The researcher has kept a diary for this study starting from June 9, 2017, when pilot interviews were conducted. This diary has recorded the plans to be made within the scope of this study, problems encountered during the research process, and especially the changes in the 
research method. Therefore, the whole research process was tried to be fully described in the researcher's diary in line with the researcher's feelings and thoughts. The interviews formed the basis of the study and the research log was also utilized to explain the interview results. Two experts were consulted during the preparation of the interview forms, analysis, and interpretation of the data, and presentation of the findings. In addition, interviews were held at each step with two experts working in the field of psychological counseling during the stages of ensuring code-theme consistency, organizing themes and sub-themes, defining the findings, and interpreting them.

The experts were consulted particularly at the stages of coding and the creation of themes and subthemes. The themes and sub-themes were restructured in line with the feedback and suggestions of the experts. The participants who agreed to a re-interview were interviewed for a second time and it was aimed to confirm by the participants whether the researcher understood the participants correctly or not. Both of the researchers took part in conducting the study.

\section{RESULTS}

Regarding the experiences of women with breast cancer in the disease process, four main themes were obtained in the study: responses to the disease process (responses to the diagnosis and after the diagnosis), coping strategies, sources of social support, and existential reflections. The findings within the framework of these main themes are explained below.

\section{Main Theme 1: Responses}

In the study, the responses of women diagnosed with breast cancer differed in the form of responses to the diagnosis and responses after the diagnosis. Table 1 shows the sub-themes relating the responses of women to the diagnosis the moment they were diagnosed with breast cancer and the responses after the diagnosis and quotation examples.

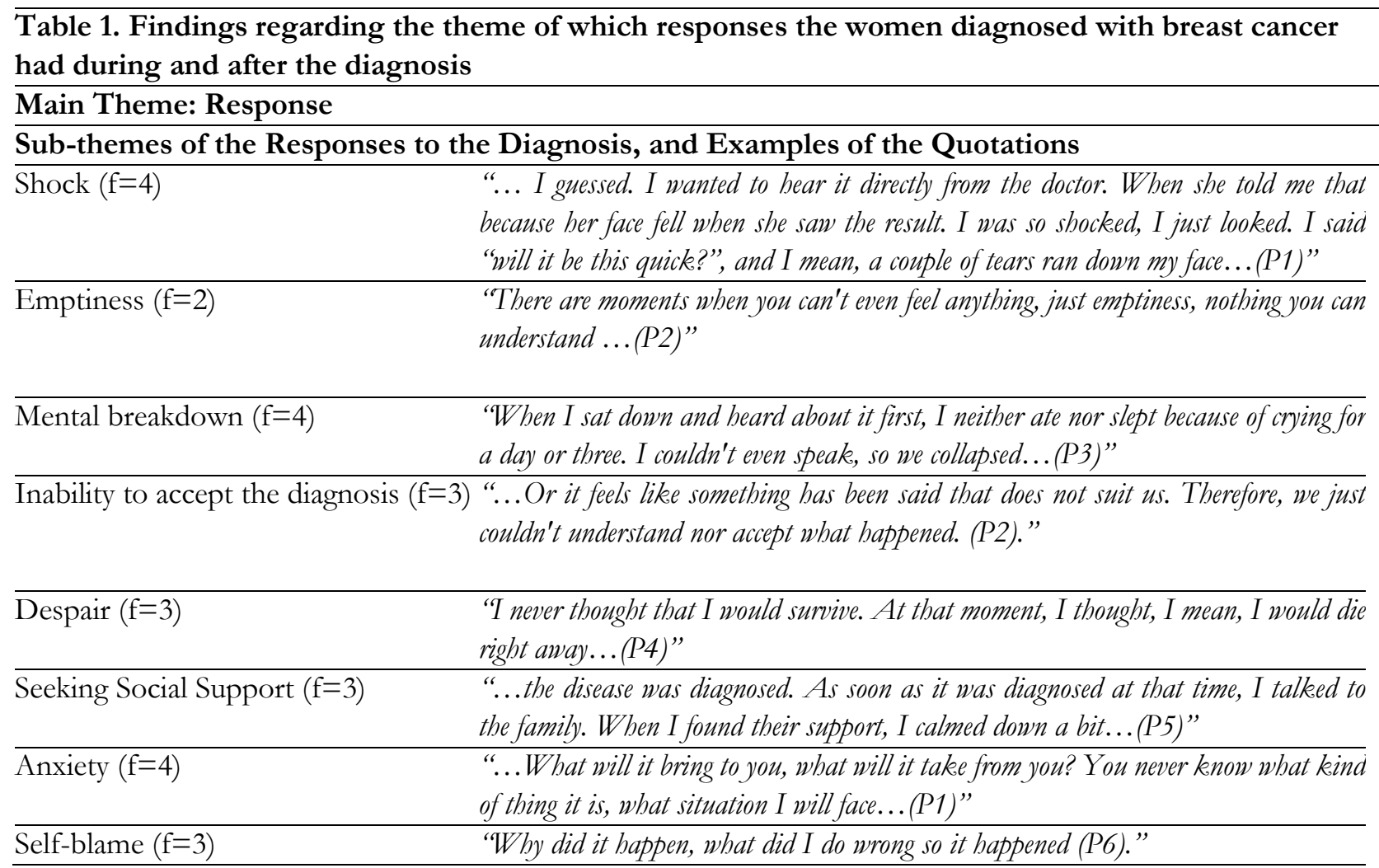




\begin{tabular}{|c|c|}
\hline \multicolumn{2}{|c|}{ Sub-themes of the Responses after the Diagnosis, and Examples of the Quotations } \\
\hline Acceptance $(\mathrm{f}=4)$ & $\begin{array}{l}\text { "...but here you are slowly starting to understand its reality. When you see that } \\
\text { everyone around you is sad and shocked... you perceive it last...(P2)" }\end{array}$ \\
\hline Anxiety $(\mathrm{f}=4)$ & $\begin{array}{l}\text { "For example, I had never seen my armpit. One day, when I raised my arm in the } \\
\text { mirror-like that, I started to cry. I locked myself in the room. (P2)." }\end{array}$ \\
\hline Sadness $(\mathrm{f}=4)$ & "That's when I was so sad when my hair fell to the ground. (P1)." \\
\hline Helplessness $(\mathrm{f}=3$ ) & $\begin{array}{l}\text { "At that time, I couldn't lift both of my arms, and you go to the toilet and someone } \\
\text { comes and pulls your pants. That was a difficult moment for me, for example. (P7)." }\end{array}$ \\
\hline
\end{tabular}

As seen in Table 1, the women's responses at the moment when they were diagnosed with breast cancer were grouped under the sub-themes of shock, emptiness, mental breakdown, denial, despair, seeking social support, anxiety, and self-blame while their responses after the diagnosis were grouped under the sub-themes of acceptance, anxiety, sadness, and helplessness. Within the framework of these sub-themes, the women stated that they could not immediately accept the diagnosis of breast cancer. It took time for them to accept that they had breast cancer; they could accept the disease process when they felt ready. The women with breast cancer expressed that they had anxieties not only during the first diagnosis but also after the diagnosis. One of the participants explained that she was very worried when thinking about the possibility of receiving new treatments for the disease. Another response that some of the women had after the diagnosis was sadness. The participants stated that hair loss, a side effect of chemotherapy, negatively affected them. Additionally, they were observed to be sad because of the loss of their organs and the loss of their physical strength. Another response after the diagnosis was helplessness. The participants expressed that they felt incapable because of needing help during the treatment. In this context, they stated that they were unable to use both arms due to mastectomy and needed constant help; they felt weak due to chemotherapy; and, they felt very incapable because they could not do anything without help.

\section{Main Theme 2: Coping Strategies}

In the study, the coping strategies used by the women diagnosed with breast cancer during the disease process were divided into the sub-themes of coping through spirituality, social support, obtaining information, exercise, and nutrition. In this context, Table 2 shows the sub-themes and quotation examples.

\begin{tabular}{|c|c|}
\hline \multicolumn{2}{|c|}{ Sub-themes of the Coping Strategies, and Examples of the Quotations } \\
\hline Coping Through Spirituality $(\mathrm{f}=6)$ & $\begin{array}{l}\text { "So, I don't think, the disease is a bad thing, as I think I have matured and can look } \\
\text { very different. The disease taught me to be more faithful. (P2)." }\end{array}$ \\
\hline $\begin{array}{l}\text { Coping Through Social Support } \\
(\mathrm{f}=6)\end{array}$ & $\begin{array}{l}\text { "My elder sister and my siblings gave me all their financial and moral support. It is also } \\
\text { a thing that lifts my morale. So, I had sincere and intimate support. (P5)." }\end{array}$ \\
\hline $\begin{array}{l}\text { Coping Through Obtaining } \\
\text { Information }(\mathrm{f}=5)\end{array}$ & $\begin{array}{l}\text { "...I just started researching. What do I do, how can I find a solution, what do I do? } \\
\text { How do I replace it and get myself together? I started reading on them all the time. (P3)" }\end{array}$ \\
\hline Coping Through Exercise $(\mathrm{f}=3$ ) & $\begin{array}{l}\text { "...Taking a walk in nature, cycling. I never left these either, I was always in nature. } \\
\text { They also have a great effect on my well-being...(P7)" }\end{array}$ \\
\hline Coping Through Nutrition $(\mathrm{f}=6)$ & $\begin{array}{l}\text { "I was very well nourished and took supplements. I also had Sheep's head soup every } \\
\text { two days. I consumed what I thought would benefit me. (P6)." }\end{array}$ \\
\hline
\end{tabular}


As seen in Table 2, one of the coping strategies used by the majority of the women with breast cancer during the disease process was coping through spirituality. The participants stated that they tried to cope with the diagnosis of breast cancer in difficult times through Allah's presence, by worshiping, and by strengthening their beliefs. As seen in Table 2, one of the participants (P7) shared that the disease taught her to be more faithful. More than half of the women diagnosed with breast cancer stated that they had difficult life due to the cancer diagnosis, that they needed the support of the people around them in these difficult times, and that they felt better when these needs were met. Another coping strategy used by half of the women with breast cancer was coping through obtaining information. At the participant statements, it was noticed that the women with breast cancer started to research the disease from the moment they were diagnosed. In addition, it was observed that they read and constantly strove to gather information to gain different perspectives on the disease and to learn what could be good for them from a psychological point of view. One of the coping strategies used by one-third of the women diagnosed with breast cancer was coping through exercise. The participants expressed that they tried to include exercise in their lives, which made them feel better. As another coping strategy, changing the diet was preferred by the majority of women with breast cancer.

\section{Main Theme 3: Sources of Social Support}

In the study, the support sources of the women with breast cancer during the disease process were collected under the sub-themes of spouse support, friend support, support of other family members, and physician support. In this context, Table 3 shows the sub-themes and quotation examples.

\begin{tabular}{|c|c|}
\hline \multicolumn{2}{|c|}{ Sub-Themes of the Sources of Social Support, and Examples of the Quotations } \\
\hline Spouse Support $(\mathrm{f}=5)$ & $\begin{array}{l}\text { "Well, my spouse always took everything on the positive side. He was constantly morale } \\
\text { for me and he was always there for me. He waited outside at every stage, at every doctor } \\
\text { check, and he gave me great support. (P7)." }\end{array}$ \\
\hline Friend Support $(\mathrm{f}=8$ ) & $\begin{array}{l}\text { "I received such great support from two friends that I cannot pay them back no matte } \\
\text { what I do. That was beautiful, that deep friendship was beautiful. (P8)." }\end{array}$ \\
\hline $\begin{array}{l}\text { Support of Other Family Members } \\
(\mathrm{f}=5)\end{array}$ & $\begin{array}{l}\text { "My sisters, I have two older sisters, they were always with me. My mother was always } \\
\text { with me, she always thought about my food, for example, my mother was always with } \\
\text { me. I can say that she fed me punctually. (P7)." }\end{array}$ \\
\hline Physician Support ( $\mathrm{f}=3$ ) & $\begin{array}{l}\text { "...the doctor was an extremely caring person, luckily. I trusted the doctors, I did exacth } \\
\text { what they said. A person I respect, an expert in the job. (P5)." }\end{array}$ \\
\hline
\end{tabular}

As seen in Table 3, one of the support sources that half of the women with breast cancer had during their disease was spouse support. The participants expressed that despite the physical and mental difficulties they faced due to the diagnosis of breast cancer, they felt better and stronger with the support they received from their spouses. In this context, as can be seen in Table 3, one of the participants (P7) stated that her spouse was always with her, gave her morale and great support. Friend support was one of the support sources that almost all the women with breast cancer had during the disease process. The participants stated that in addition to the support they got from their spouse, feeling the support of their friends gave them morale and made them feel valued. Another source of support that half of the women with breast cancer had during the disease process in addition to spouse and friend support was the support of other family members. The participants shared that the support they received from their family members was an important source of support for them. Another source of support that one-third of the women diagnosed with breast cancer received during the disease process was the support they received 
from their physicians. The participants generally stated that they received support from both their oncologists and psychiatrists during the process.

\section{Main Theme 4: Existential Reflections}

In the study, the existential reflections experienced by the women diagnosed with breast cancer during the disease process were taken as the sub-themes of maturing, re-interpreting life, and facing death. In this context, Table 3 shows the sub-themes and quotation examples.

\begin{tabular}{|c|c|}
\hline \multicolumn{2}{|c|}{ Sub-themes of the Existential Reflections, and Examples of the Quotations } \\
\hline Maturing $(\mathrm{f}=7)$ & $\begin{array}{l}\text { "... I generally look at life positively. I even look better after the disease. I started to } \\
\text { find more positive covers for things that seem negative in my head. (P2)." }\end{array}$ \\
\hline Re-Interpreting Life $(\mathrm{f}=6)$ & $\begin{array}{l}\text { "Being in the moment. If it had been before, I would have thought of the past or the } \\
\text { after. It is not like that now. I am here now and I am healthy. I enjoy the moment, } \\
\text { it's that clear. (P5)." }\end{array}$ \\
\hline Facing Death $(\mathrm{f}=7)$ & $\begin{array}{l}\text { "... How should I define myself? I mean I came to life and life is short. Cancer also } \\
\text { underlined this in a way, but it is something we already know well. Maybe if you } \\
\text { ask, } 90 \text { people out of } 100 \text { will say that. This is now a fact that I have taken as a } \\
\text { motto for my life, not just words. (P6)." }\end{array}$ \\
\hline
\end{tabular}

As seen in Table 4, the majority of the women with breast cancer stated that their awareness about themselves increased and that they matured during the diagnosis and treatment process. They shared that with the disease process, they thought about themselves, questioned themselves, their personality, and behaviors, and found new answers about themselves due to the disease experience. More than half of the women diagnosed with breast cancer expressed that they questioned the meaning of life and created new meanings during the diagnosis and treatment process. In this regard, one of the participants (P5) stated in the interview that she enjoyed being in the moment and did not think about the past or the after, as before. Most of the women diagnosed with breast cancer shared that their awareness about death increased during the disease process.

\section{DISCUSSION}

This study's findings revealed that the disease process experiences of women with breast cancer in the psychosocial context were gathered under the main themes of responses to the disease, coping strategies, sources of social support, and existential reflections. The initial response of nearly half of the women with breast cancer to the diagnosis was to be shocked. The studies also show that one of the first responses that women with breast cancer have when they learn about their disease is shock (Landmark \& Wahl, 2002; Tunç, 2014; Inan et al., 2016; Lie et al., 2018). These findings indicate that when women with breast cancer find out about the disease, this news traumatizes them: They get shocked; they get anxious because they feel threatened by death; and, they cannot find the strength to cope with this anxiety at first.

The literature findings present that a few women diagnosed with breast cancer could not think of anything when they heard the diagnosis: They thought that their brains stopped working, and they could only nod to what the doctor said (Liamputtong \& Suwankhong, 2015); they felt emptiness as an emotional response (Tunç, 2014). These findings are also in line with the current study findings. The study shows that nearly half of the women with breast cancer go through emotional devastation when they get 
diagnosed, do not know what to think, what to do, and how to feel in the face of the threat of nonexistence, and experience a sense of emptiness. In addition, in the study, nearly half of the women with breast cancer were found to experience a kind of depression when they get diagnosed. Related studies in the literature also prove that the first responses of women with breast cancer to the diagnosis are sadness and questioning the cause of the disease (Lam et al., 2018; Tunç, 2014), and constantly crying (Inan et al., 2016). In this context, it is possible that women with breast cancer may feel emotionally confused regarding the diagnosis and perceive the disease as a devastating situation. About the findings for the response of inability to accept the diagnosis, there are similar findings in the literature. Many studies show that when women with breast cancer hear about the diagnosis, they do not want to accept this situation and think that it is impossible (Çömez \& Karayurt, 2016; Dsouza et al., 2018). They do not accept the treatment because they do not accept the disease (Hajian et al., 2017), and they think that they have misunderstood the situation (Lie et al., 2018). Similar to these findings, Kübler-Ross (2010) states that denial is the first stage of the responses to cancer and that denying the situation is a defense system that protects the individual from danger and threat.

Some women diagnosed with breast cancer also think that the moment they hear about the disease, everything is over: They will not be able to live anymore and they will not be able to get rid of this situation. When the literature is examined, it is seen that women diagnosed with breast cancer fell into despair at the moment they got diagnosed; they thought that the disease could not be cured and that there was no effective treatment method (Inan et al., 2016). Thus, it can be stated that individuals experience deep pain, loneliness, and helplessness because they realize that they have nothing to do in the face of the reality of death. In addition, some of the participants shared that after the diagnosis they talked to their families, went to their neighbors, and shared the news. Consistent with this finding, the relevant study findings also show that the individuals feel the need to talk to someone when they hear the diagnosis, and call their families (Tunç, 2014; Lie et al., 2018). Therefore, it can be said that women diagnosed with breast cancer need to be understood and need appropriate support when they get diagnosed; and, meeting their needs is also very important in fighting the disease. Some of the women diagnosed with breast cancer also stated that when they learned about the disease, they blamed themselves for thinking that they were sick because they were eating unhealthily, smoking, doing something wrong, and not taking care of themselves. The studies indicate that women with breast cancer experience intense guilt because of past unhealthy behaviors (Kim et al., 2012), previous mistakes that might have caused cancer (Tunç, 2014), unhealthy diet, and delaying the examinations (Hajian et al., 2017). In this context, it is thought that the individuals associate the disease with their mistakes in their lives and can blame themselves, especially by turning to their past lives.

The responses which the women with breast cancer had during the diagnosis differ after the diagnosis. The women's responses after the diagnosis include the sub-themes of acceptance, anxiety, sadness, and helplessness. These findings show that women with breast cancer had to reorganize their lives during the disease process, especially after the diagnosis. Nearly half of the women showed responses of accepting their disease during the post-diagnosis process; on the other hand, they felt sad, afraid, guilty, and desperate in the face of the changes/losses in their life and body and the threat of death, which were caused by the disease. The studies on acceptance of the disease exhibit that women with breast cancer accept the situation and believe that treatment is needed to recover (Lam et al., 2018) and that they feel strong in terms of spirituality after the acceptance (Van Ee et al., 2019). Therefore, it can be stated that 
although accepting the disease is quite difficult for women with breast cancer, it is very important for individuals to evaluate the situation realistically and to decide on treatment options, and take action.

In the interviews, nearly half of the women with breast cancer shared that they were worried about their appearance and the possibility of recurrence after the treatment. The study findings also reveal that women feel anxious, suffer, and feel insecure because they think that this disease will reoccur and that they will die (Drageset et al., 2020), and because they do not know how long they will live (Levkovich, 2019). In addition, nearly half of the women with breast cancer in the study expressed that they got sad when their hair was shedding as a result of the side effects of the treatment, when their veins were weakening, and when they lost an organ as a result of a mastectomy. The studies in the literature also point out that women with breast cancer feel incomplete, suffer, and feel sad due to organ loss after mastectomy (Olasehinde et al., 2019; Hammoudeh et al., 2017) and they experience sadness due to hair loss (Hammoudeh et al., 2017; Cebeci, et al., 2012). Moreover, some of the women diagnosed with breast cancer in the study stated that they felt incapable because they could not do anything they wanted to do, and had to get help due to the side effects of the treatment. The findings of the literature also reflect that women with breast cancer feel very helpless when they think that the disease cannot be cured, when they wait without doing anything (Lam et al., 2018), and due to the possibility of recurrence of the disease (Levkovich, 2019). Based on the findings of the study, it can be stated that women with breast cancer feel helpless and incapable during the disease process in the face of the possibility of recurrence and due to the loss of physical strength because of the side effects of the treatment.

Coping strategies used by the women with breast cancer during the disease process were determined under the sub-themes of coping strategies through spirituality, social support, obtaining information, exercise, and nutrition. Therefore, the women diagnosed with breast cancer used different coping methods for the compelling effects of the disease during the disease process and changed their strategies in line with the emotional turmoil they experienced. One of the coping strategies used by the majority of women diagnosed with breast cancer is coping through spirituality. This finding corresponds to the findings in the literature. The findings of the literature also indicate that women with breast cancer become more faithful during the disease process (Cebeci et al., 2012) as faith gives them strength (Tunç, 2014), and they can cope with anxiety and depression more easily through spirituality (Geyikçi et al., 2018). Therefore, coping through spirituality supports women with breast cancer during the disease process. However, it should be remembered that the fatalistic approach may adversely affect the women's action in coping with the disease.

In the study, many of the women with breast cancer shared that they received great financial and moral support from their families and friends. These people were always with them during the diagnosis and treatment process; thanks to their support, their troubles got alleviated and they forgot their pain. In the literature, it is seen that women with breast cancer cope with the disease by seeking social support during the diagnosis and treatment process (Lie et al., 2018), feel relieved when they share their experiences with individuals diagnosed (Gibbons \& Groarke, 2018; Caleffi et al., 2017), receive sufficient support from family members and friends (Lofti, 2017; Caleffi et al., 2017; Cebeci et al., 2012), and receive both sufficient (Caleffi et al., 2017) and insufficient support (Lofti, 2017) from healthcare personnel. It was found in this study that the women got the support of their spouses, friends, other family members, and physicians as sources of social support. In this context, perceiving the social support women with breast cancer need in the diagnosis and treatment process as sufficient is important for individuals to gain 
emotional strength and to feel ready to fight the disease. Thus, it can be stated that women with breast cancer need to feel that they are not alone and to establish relationships with other people.

Another coping strategy used by half of the women with breast cancer during the disease process was coping through obtaining information. The women diagnosed with breast cancer stated that they consulted doctors, conduct research online, watch psychiatrists' programs, and read books to get information about the disease. In line with these findings, it can be stated that women with breast cancer need information from the moment they get diagnosed. A study shows that individuals with breast cancer need to learn more about the treatments and their side effects (Morrison et al., 2012). Therefore, to eliminate the question marks in their minds and to accept the disease and take action, women with breast cancer need to have access to the correct information at the right time from professionals working in healthcare. In addition, a few of the women said in the interviews that it was very good for them to walk outdoors: They had regular walks in nature; they forced themselves and went out for a walk even on days when they felt tired. When the relevant studies are examined, it is seen that the individuals increase their quality of life with exercise during the disease process (Jacobsen et al., 2013; Hagstrom et al., 2016), aim to regain feelings of control, change their eating habits, and eat healthier (Gibbons \& Groarke, 2018). In the current study, many of the women diagnosed with breast cancer expressed that they tried to have a healthy diet, stopped eating sugar, and ate mostly vegetables and fruits after their diagnosis. Therefore, the study findings are in line with the previous findings.

Half of the participants stated that one of the support sources they had during the disease process was spouse support. In the interviews, the women with breast cancer shared that they received great support from their spouse, that they materially and morally felt their spouse's support always with them, and that their spouse never upset them. In the studies on the experiences of women with breast cancer during the disease process, spouse support is concluded as being a very important source of social support (Liamputtong \& Suwankhong, 2015). In addition, the study results reveal that spouse support has a decisive role in providing psychosocial needs (Tunç, 2014) and emotional support (Ghaemi et al., 2019) of individuals with breast cancer. In this context, it is said that the most important sources of support for women with breast cancer in the disease process are spouse support (Salakari et al., 2017). In the interviews conducted in the current study, almost all the women with breast cancer stated that they received a lot of support from their friends, that they never felt lonely, that they often met with their friends, and that surprises were prepared for them. The studies show that friend support is an important source of support in meeting the psychosocial needs of individuals with breast cancer (Tunç, 2014). Thus, for women diagnosed with breast cancer, friend support can be as much functional as spouse support.

Another source of social support that half of the women had during the disease is the support of other family members. In the interviews, the women with breast cancer expressed that they received a lot of support from their mothers, siblings, and cousins, they especially received care support from these people, and they were never alone. The studies show that the support of family members has a facilitating effect on coping with the disease (Koosha et al., 2017). In addition, it is stated that talking with their families and loved ones about the disease works like a therapy for individuals with breast cancer (Drageset et al., 2010). Therefore, family support which is perceived sufficient during the disease process can have a psychologically protective effect on women with breast cancer. Additionally, in the interviews, a few of the women with breast cancer expressed that they trusted doctors a lot, that their oncologists gave them morale, that they followed exactly what these people said them to do, and that they felt relieved when 
they met with psychiatrists. The studies conducted in this context show that oncologists provide emotional support about treatment to individuals with breast cancer (Toledo et al., 2019) and give information support to them (Chawak et al., 2019). In this context, it can be stated that physician support, when perceived as sufficient by women diagnosed with breast cancer, can positively affect both the wellbeing of the individuals and the course of the disease.

In this study, it is revealed that the women with breast cancer also experienced existential changes, rethought the meaning of their lives, and faced death during the disease process. In the study, it was concluded that the majority of women with breast cancer matured during the disease process after the diagnosis of cancer. In the literature, the studies show that the individuals think more positively and are happier (Van Ee et al., 2019; Llewellyn et al., 2019), that they learn to say no, that they are more tolerant, and that they evaluate stressors more positively (İnan \& Üstün, 2020) and develop a more positive selfperception (Cebeci et al., 2012) during the disease process. On the other hand, another study shows that the change of individuals with breast cancer is on the negative side. Their tolerance decreases after the diagnosis; they constantly complain and react by thinking "why me?"; and, their negative thoughts increase (Ghaemi et al., 2019). In line with the study findings, it can be stated that the experience of breast cancer enables the women to mature, to appreciate every moment they live, and to increase their awareness of death, as well as leading them to think about their own lives with increased awareness.

More than half of the participants shared that due to the disease, they re-examined their lives and they understood the value of living in the present and living without thinking about tomorrow. In the literature, it is presented that because of the disease, new values in the lives of individuals with breast cancer have occurred (Inan \& Üstün, 2020): They understand the value of being alive, and the disease has brought new perspectives to them (Drageset et al., 2020); they are more grateful for their living and they do not worry about the little things anymore (Llewellyn et al., 2019). Although cancer diagnosis poses an existential threat for women (Drageset et al., 2011), experiencing the disease is thought to bring about a positive change and more meaning for the women (Silva et al., 2012). Therefore, it can be stated that due to the cancer experience, women reconsider how they want to continue to live their remaining lives, their priorities, the people they want to have in their lives, and what will make them happy and that they want to continue their lives with new meanings.

In this study, many of the women with breast cancer stated that during the disease process they thought they would die when they learned the diagnosis, experienced fear of death, faced death due to the disease and felt relieved when they accepted death. In the studies, individuals with breast cancer expressed that they thought about death inevitably and feared it due to the diagnosis of the disease (Drageset et al., 2016; ALmegewly et al., 2019; Ghaemi et al., 2019; İnan \& Üstün, 2020), and thought suddenly about how much time they had to live (Llewellyn et al., 2019). In this context, these findings support this study's findings. Based on the current findings, it can be expressed that due to the cancer diagnosis, women realize that they are mortal, and they are afraid and cannot stop themselves from thinking about death. It can be thus stated that women with breast cancer feel helpless and intense anxiety in the face of the thought that death is approaching and that it may come at any moment. Their anxiety decreases when they accept that they are mortal. 


\section{Conclusions and Suggestions}

As a result, the findings obtained from the interviews with the women with breast cancer in this study revealed the themes of responses in the disease process, coping strategies, sources of social support, and existential reflections. In this context, this study presents detailed information about the difficulties experienced by women with breast cancer during the disease process and reveals the support sources and coping strategies they have during the disease process. Besides, this study also reflects the perspectives of women with breast cancer about the meaning of life and death during the disease process. The study is particularly notable for showing the positive effects of cancer on women's lives, despite it being a challenging experience.

In this context, some suggestions can be made based on the findings. Within this scope, it is thought that establishing peer groups for women with breast cancer and conducting closed group guidance practices for emotion regulation will be very helpful for professionals working in the field of mental health. Additionally, it would be beneficial to have psycho-education practices to increase the psychological resilience and coping skills of women with breast cancer and their relatives to develop the coping strategies used during the disease process. On the other hand, current findings should be considered with the limitations of the research. This research was carried out based on a phenomenological design that aims to reveal the experiences of 10 women diagnosed with breast cancer during the disease process in a psycho-social context. Therefore, there is a need to repeat the study with other women who have breast cancer, and to carry it out by using different research methods to further expand the existing findings and to explain the psychosocial aspects of the breast cancer experience. In this context, future studies may examine the lives of breast cancer patients in long-term, obtain patients' experiences via focus groups, or research the experiences of breast cancer patients' families and healthcare professionals which would help reveal the psychosocial outcomes of breast cancer and contribute to the providing of more effective psychological assistance to breast cancer patients. 


\section{REFERENCES}

Ahadi, H., Delavar, A. \& Rostami, A. M. (2014). Comparing coping styles in cancer patients and healthy subjects. Procedia-Social and Behavioral Sciences, 116, 3467-3470. https: //doi.org/10.1016/j.sbspro.2014.01.785

Akturan, U. \& Esen, A. (2013). Fenomenoloji. In T. Baş \& U. Akturan (Eds.), Nitel araştırma yöntemleri (pp. 83-98). Seçkin.

ALmegewly, W., Gould, D. \& Anstey, S. (2019). Hidden voices: An interpretative phenomenological analysis of the experience of surviving breast cancer in Saudi Arabia. Journal of Research in Nursing, 24(1), 122-132. https://doi.org/ 10.1177/1744987118809482

Babacan Gümüş, A. (2006). Meme kanserinde psikososyal sorunlar ve destekleyici girişimler. Meme Să̆h̆ğ Dergisi, 2(3), 108-114. $\quad$ http://www.thejournalofbreasthealth.com/archives/archive-detail/articlepreview/psychosocal-ssues-n-breast-cancer-and-supportve-nt/42708

Caleffi, M., Burchardt, N. A., Crivelatti, I., Gomes, A. L., Gomes, C. \& Pohlmann, P. (2017). Coping with metastatic breast cancer: The patients' perspective in a Brazilian cancer center. The Breast, 36, 3845. https://doi.org/10.1016/S0960-9776(17)30670-7

Cebeci, F., Yangin, H. B. \& Tekeli, A. (2012). Life experiences of women with breast cancer in South western Turkey: A qualitative study. European Journal of Oncology Nursing, 16(4), 406-412. https://doi.org/10.1016/i.ejon.2011.09.003

Chawak, S., Chittem, M., Butow, P. \& Huilgol, N. (2019). Indian cancer patient's needs, perceptions of and expectations from their Support Network: A qualitative study. Journal of Cancer Education, 35, 462-469. https://doi.org/10.1007/s13187-019-1483-4

Curtis, R., Groarke, A., McSharry, J. \& Kerin, M. (2014). Experience of breast cancer: burden, benefit, or both? Cancer Nursing, 37(3), 21-30. https://doi.org/10.1097/NCC.0b013e3182894198

Çömez, S. \& Karayurt, Ö. (2016). We as spouses have experienced a real disaster: A qualitative study of women with breast cancer and their spouses. Cancer Nursing, 39(5), 19-28. https://doi.org/10.1097/NCC.0000000000000306

Drageset, S., Lindstrøm, T. C. \& Ellingsen, S. (2020). "I have both lost and gained." Norwegian survivor's experiences of coping 9 years after primary breast cancer surgery. Cancer Nursing, 43(1), 30-37. https://doi.org/10.1097/NCC.0000000000000656

Drageset, S., Lindstrøm, T. C., \& Underlid, K. (2010). Coping with breast cancer: between diagnosis and surgery. Journal of Advanced Nursing, 66(1), 149-158. https://doi.org/10.1111/j.1365-2648.2009.05210.x

Drageset, S., Lindstrøm, T. C., Giske, T. \& Underlid, K. (2011). Being in suspense: Women's experiences awaiting breast cancer surgery. Journal of Advanced Nursing, 67(9), 1941-1951. https://doi.org/10.1111/j.13652648.2011.05638.x

Drageset, S., Lindstrøm, T. C. \& Underlid, K. (2016). "I just have to move on": Women's coping experiences and reflections following their first year after primary breast cancer surgery. European Journal of Oncology Nursing, 21, 205-211. https://doi.org/10.1016/i.ejon.2015.10.005

Dsouza, S. M., Vyas, N., Narayanan, P., Parsekar, S. S., Gore, M. \& Sharan, K. (2018). A qualitative study on experiences and needs of breast cancer survivors in Karnataka, India. Clinical Epidemiology and Global Health, 6(2), 69-74. https://doi.org/10.1016/j.cegh.2017.08.001

Elbi, H. (2001). Kanser ve Depresyon. Psikiyatri Dünyasi, 5(1), 5-10. http: $/ /$ psikivatridizini.net $/$ articles.aspx?journalid $=21$ \&year $=2001 \&$ volume $=5 \&$ number $=1$

Finfgeld-Connett, D. (2005). Clarification of social support. Journal of Nursing Scholarship, 37(1), 4-9. https://doi.org/10.1111/j.1547-5069.2005.00004.x

Geyikçi, R., Çakmak, S., Demirkol, M. E. \& Uguz, Ş. (2018). Correlation of anxiety and depression levels with attitudes towards coping with illness and sociodemographic characteristics in patients with a diagnosis of 
breast cancer. Düşünen adam: Journal of Psychiatry and Neurological Sciences, 31(3), 246-257. https://doi.org/10.5350/DAJPN2018310302

Ghaemi, S. Z., Keshavarz, Z., Tahmasebi, S., Akrami, M. \& Heydari, S. T. (2019). Explaining perceived priorities in women with breast cancer: A qualitative study. Asian Pacific Journal of Cancer Prevention, 20(11), 3311-3319. https://doi.org/10.31557/APJCP.2019.20.11.3311

Gibbons, A. \& Groarke, A. (2018). Coping with chemotherapy for breast cancer: Asking women what works. European Journal of Oncology Nursing, 35, 85-91. https://doi.org/10.1016/i.ejon.2018.06.003

Hagstrom, A. D., Marshall, P. W., Lonsdale, C., Cheema, B. S., Fiatarone Singh, M. A. \& Green, S. (2016). Resistance training improves fatigue and quality of life in previously sedentary breast cancer survivors: A randomized controlled trial. European Journal of Cancer Care, 25(5), 784-794. https://doi.org/10.1111/ecc.12422

Hajian, S., Mehrabi, E., Simbar, M. \& Houshyari, M. (2017). Coping strategies and experiences in women with a primary breast cancer diagnosis. Asian Pacific Journal of Cancer Prevention: APJCP, 18(1), 215-224. https://doi.org/10.22034/APJCP.2017.18.1.215

Hammoudeh, W., Hogan, D. \& Giacaman, R. (2017). From a death sentence to a disrupted life: Palestinian women's experiences and coping with breast cancer. Qualitative Health Research, 27(4), 487-496. https://doi.org/10.1177/1049732316628833

İnan, F. Ş. \& Üstün, B. (2020). Post-traumatic growth in the early survival phase: From Turkish breast cancer survivor's perspective. European Journal of Breast Health, 16(1), 66-71. https://doi.org/10.5152/ejbh.2019.5006

İnan, F. Ş., Günüşen, N. P. \& Üstün, B. (2016). Experiences of newly diagnosed breast cancer patients in Turkey. Journal of Transcultural Nursing, 27(3), 262-269. https://doi.org/10.1177/1043659614550488

Jacobsen, P. B., Phillips, K. M., Jim, H. S., Small, B. J., Faul, L. A., Meade, C. D. \& Wilson, R. W. (2013). Effects of self-directed stress management training and home-based exercise on quality of life in cancer patients receiving chemotherapy: A randomized controlled trial. Psycho-Oncology, 22(6), 1229-1235. https://doi.org/10.1002/pon.3122

Kim, I. R., Cho, J. H., Choi, E. K., Kwon, I. G., Sung, Y. H., Lee, J. E. \& Yang, J. H. (2012). Perception, attitudes, preparedness, and experience of chemotherapy-induced alopecia among breast cancer patients: A qualitative study. Asian Pacific Journal of Cancer Prevention, 13(4), 1383-1388. http://dx.doi.org/10.7314/APJCP.2012.13.4.1383

Koosha, M., Raoofi, A., Bahrami, A., Sajadian, A., Tafazzoli-Harandi, H. \& Haghighat, S. (2017). Mothers and sisters are the most effective sources of support in coping with the disease in patients with breast cancer. Multidisciplinary Cancer Investigation, 1(3), 15-21. https://doi.org/10.21859/mci-01034

Kübler Ross, E. (2010). Ölüm ve ölmek ürerine [On death and dying]. April.

Lam, W. W. T., Fielding, R., Yoon, S. W., Tsang, J. \& Soong, I. (2018). Living with advanced breast cancer in women resilient to distress versus women with persistent distress: a qualitative study. Hong Kong Medical Journal, 24(4), 38-41. https://www.hkmj.org/system/files/hkmj1804sp4p38.pdf

Landmark, B. T. \& Wahl, A. (2002). Living with newly diagnosed breast cancer: A qualitative study of 10 women with newly diagnosed breast cancer. Journal of Advanced Nursing, 40(1), 112-121. https://doi.org/10.1046/j.1365-2648.2002.02346.x

Levkovich, I. (2019). "The danger still hangs over my head" fear of recurrence among Israeli breast cancer survivors. Journal of Health Sciences, 9(1), 23-33. https://doi.org/10.17532/jhsci.2019.687

Liamputtong, P. \& Suwankhong, D. (2015). Breast cancer diagnosis: Biographical distuption, emotional experiences, and strategic management in Thai women with breast cancer. Sociology of Health and Illness, 37(7), 1086-1101. https://doi.org/10.1111/1467-9566.12282 
Lie, N. E. K., Larsen, T. M. B. \& Hauken, M. A. (2018). Coping with changes and uncertainty: A qualitative study of young adult cancer patient's challenges and coping strategies during treatment. European Journal of Cancer Care, 27(6), 1-10. https://doi.org/10.1111/ecc.12743

Llewellyn, A., Howard, C. \& McCabe, C. (2019). An exploration of the experiences of women treated with radiotherapy for breast cancer: Learning from recent and historical cohorts to identify enduring needs. European Journal of Oncology Nursing, 39, 47-54. https://doi.org/10.1016/j.ejon.2019.01.002

Lofti, S. (2017). Meme kanseri hastası yoksul kadın olmak: Başetme ve sosyal destek süreçlerinin incelenmesi [Being a women with breast cancer: Investigation of coping and social support process] (Publication No: 469254). [Doctoral dissertation, Hacettepe University]. YÖKTEZ.

Moadel, A., Morgan, C., Fatone, A., Grennan, J., Carter, J., Laruffa, G. \& Dutcher, J. (1999). Seeking meaning and hope: Self-reported spiritual and existential needs among an ethnically-diverse cancer patient population. Psycho-Oncology: Journal of the Psychological, Social and Behavioral Dimensions of Cancer, 8(5), 378-385. https://doi.org/10.1002/(SICI)1099-1611(199909/10)8:5<378::AID-PON406>3.0.CO;2-A

Morrison, V., Henderson, B. J., Zinovieff, F., Davies, G., Cartmell, R., Hall, A. \& Gollins, S. (2012). Common, important, and unmet needs of cancer outpatients. European Journal of Oncology Nursing, 16(2), 115-123. https://doi.org/10.1016/i.ejon.2011.04.004

Olasehinde, O., Arije, O., Wuraola, F. O., Samson, M., Olajide, O., Alabi, T. \& Kingham, T. P. (2019). Life without a breast: Exploring the experiences of young Nigerian women after mastectomy for breast cancer. Journal of Global Oncology, 5, 1-6. https://doi.org/10. 1200/JGO.18.00248

Özkan, S. (1993). Psikiyatrik tıp: konsültasyon liyezon psikiyatrisi. Roche İlaç Sanayi A.Ş.

Özkan, S., \& Alçalar, N. (2009). Meme kanserinin cerrahi tedavisine psikolojik tepkiler. Meme Sağğğ Dergisi / Journal of Breast Health, 5 (2), 60-64. https://web.a.ebscohost.com/abstract?direct=true\&profile= ehost\&scope $=$ site \&authtype $=$ crawler\&jinl $=13060945 \& \mathrm{AN}=37836214 \& \mathrm{~h}=2 \mathrm{VsohvL} 8 \mathrm{Obux} 5 \mathrm{k} 24 \mathrm{OwN}$ mmNZYz6jtGqsonLE6LmGUpnr720tjZl\%2fUff9WBWi2i4itsRs28tR9xj1O8Hbit \%2fqTNA\%3d\%3d\&

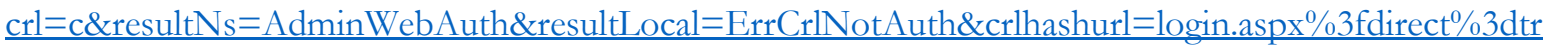
ue $\% 26$ profile $\% 3$ dehost $\% 26$ scope $\% 3$ dsite $\% 26$ authtype $\% 3$ dcrawler $\% 26 j$ rnl $\% 3 \mathrm{~d} 13060945 \% 26 \mathrm{AN} \% 3 \mathrm{~d} 37$ $\underline{836214}$

Salakari, M., Pylkkänen, L., Sillanmäki, L., Nurminen, R., Rautava, P., Koskenvuo, M. \& Suominen, S. (2017). Social support and breast cancer: A comparative study of breast cancer survivors, women with mental depression, women with hypertension and healthy female controls. The Breast, 35, 85-90. https://doi.org/10.1016/j.breast.2017.06.017

Silva, S. M., Crespo, C., \& Canavarro, M. C. (2012). Pathways for psychological adjustment in breast cancer: A longitudinal study on coping strategies and posttraumatic growth. Psychology and Health, 27(11), 1323-1341. http://dx.doi.org/10.1080/08870446.2012.676644

Taleghani, F., Yekta, Z. P. \& Nasrabadi, A. N. (2006). Coping with breast cancer in newly diagnosed Iranian women. Journal of Advanced Nursing, 54(3), 265-272. https://doi.org/10.1111/j.1365-2648.2006.03808 1.x

Toledo, G., Ochoa, C. Y. \& Farias, A. J. (2019). Abstract P5-13-16: Exploring the role of social support and adjuvant endocrine therapy use among breast cancer survivors. Supportive Care in Cancer, 28(1), 271-278. https://doi.org/10.1007/s00520-019-04814-0.

Tunç. A. (2014). Meme kanseri tanısı almış kadınların hastalık temsilleri, başa çıkma stratejileri, kaygı ve depresyon düzeyleri arasındaki ilişkilerin incelenmesi ile psiko-sosyal ihtiyaçlarının belirlenmesi [Assessment of the relationships among illness representations, coping, anxiety and depression levels of women illness diagnosed with breast cancer and defining their psycho-social needs] (Publication No: 370195). [Doctoral dissertation, Mersin University]. YÖKTEZ.

Van Ee, B., Smits, C., Honkoop, A., Kamper, A., Slaets, J., \& Hagedoorn, M. (2019). Open wounds and healed scars: A qualitative study of elderly women's experiences with breast cancer. Cancer Nursing, 42(3), 190-196 https://doi.org/10.1097/NCC.0000000000000575 


World $\begin{gathered}\text { Health } \\ \text { https://www.who.int/cancer/PRGlobocanFinal.pdf }\end{gathered}$
$\underline{\text { Oration }}$

Yeter, K., Savci, A. \& Sayiner, F. D. (2009). Meme kanserinde rekonstrüktif cerrahinin ve hasta eğitiminin yaşam kalitesine etkisi. Meme Sağh̆ğ Dergisil Journal of Breast Health, 5(2), 65-68. http://www.thejournalofbreasthealth.com/archives/archive-detail/article-preview/the-effects-of-qualtyof-lfe-on-reconstructve-surg/42583

Yıldırım, A. \& Şimşek, H. (2016). Sosyal Bilimlerde Nitel Araştırma Yöntemleri [Qualitative research methods for the social scinces]. Seçkin. 


\section{About Authors}

Didem Şimşek Öcal completed her undergraduate education at the Department of Psychological Counseling and Guidance at Çukurova University. She received her Master's degree Department of Psychological Counseling and Guidance at Çukurova University. She received PhD degree Department of Psychological Counseling and Guidance at Anadolu University. She is working as an psychological counselor at MEB since 2008.

Aydoğan Aykut Ceyhan is currently an professor in the Department of Psychological Counseling and Guidance at Anadolu University, Eskişehir, Turkey. He is interested in problematic internet use, internet addiction.

\section{Author Contributions}

DŞÖ: Idea and design, data collection and analysis, interpretation of findings, reporting of the article.

AAC: Idea and design, data analysis, interpretation of findings, reporting of the article.

\section{Conflict of Interest}

It has been reported by the authors that there is no conflict of interest.

\section{Funding}

No funding support was received.

\section{Note}

The current research contains a part of a doctoral thesis of the corresponding author titled The Disease Process Experiences of Women Diagnosed with Breast Cancer in the Psycho-Social Context. This thesis was conducted under the supervision of Prof. Dr. A. Aykut Ceyhan who was the second author

\section{Ethical Statement}

The authors declare that they have carried out the research within the framework of the Helsinki Declaration and with the participation of volunteer students. In line with this, the study was permitted by Anadolu University, Ethics Committee.

Ethics Committee Name: Anadolu University, Ethics Committee

Approval Date: 13.01.2017

Approval Document Number: 5900 